\title{
Procurement management of input and factors influencing commercial broiler rearing in Dharwad district
}

SHREYA V. AMARAPURKAR, C. MURTHY AND J.A. MULLA

Received : 06.08.2014; Revised : 22.08.2014; Accepted : 06.09.2014

\begin{abstract}
Poultry farming in India has been a huge success in the last decade. Statistics showed a 2 per cent increase per annum in the agricultural production during the last 30 years, while the growth in the poultry sector has been 12 per cent which gives an idea about how well this industry is doing. The Indian poultry industry has grown largely due to the initiative of private enterprises. Poultry farming in India is a culmination of many years of innovation. Moreover, today the industry as a whole, with its enabling of low cost model with increased productivity. The procurement cost increases as the net income also increases. There are a total of 15 factors relating to production, marketing, socio-economic characters, contracting terms which were considered and subjected to principal component analysis. In this principal component analysis, six dimensions were extracted and considered for interpretation.
\end{abstract}

KEY WORDS : Factor analysis, Procurement, Commercial broiler

How to cite this paper : Amarapurkar, Shreya V., Murthy, C. and Mulla, J.A. (2014). Procurement management of input and factors influencing commercial broiler rearing in Dharwad district. Internat. J. Com. \& Bus. Manage., 7(2) : 325-328.

\section{MEMBERS OF THE RESEARCH FORUM}

Correspondence to:

SHREYA V. AMARAPURKAR, Department of Agri-business Management, University of Agricultural Sciences, DHARWAD (KARNATAKA) INDIA

Email: shreya.amarapurkar@gmail.com

Authors' affiliations:

C. MURTHY, Department of Agri-business Management, College of Agriculture, University of Agricultural Sciences, DHARWAD (KARNATAKA) INDIA

J.A. MULLA, Department of Animal Science, College of Agriculture, University of Agricultural Sciences, DHARWAD (KARNATAKA) INDIA 